\title{
Tissue factor-targeted immunotherapy of melanoma and triple negative breast cancer using a second generation ICON
}

\author{
Zhiwei Hu*, Elizabeth McMichael, Amanda Campbell, Cheryl A London, William E Carson
}

From 30th Annual Meeting and Associated Programs of the Society for Immunotherapy of Cancer (SITC 2015) National Harbor, MD, USA. 4-8 November 2015

\section{Background}

$\mathrm{Hu}$ and colleagues have identified tissue factor (TF-the primary initiator of coagulation and a modulator of angiogenesis) as a common yet specific biomarker and therapeutic target on a variety of cancer cells and angiogenic tumor vascular endothelial cells [1-3]. He has co-invented a TF-targeting Immuno-Conjugate agent named ICON that consists of factor VII (1-406 aa, the natural ligand to tissue factor) fused to the Fc region of $\operatorname{IgG} 1[1,2,4,5]$.
Intra-lesional ICON therapy of experimental murine melanoma tumors with an adenoviral vector leads to marked growth tumor inhibition with minimal effects on normal tissues [1]. However, ICON has a relatively big molecular weight $(210 \mathrm{kDa})$ (Figure 1) [5]. To reduce its molecular mass, $\mathrm{Hu}$ has developed a second generation ICON, named L-ICON, which consists of only the light chain (1-152 aa) of fVII fused to IgG1Fc (Figure 1). This proposal is designed to evaluate the effects of L-ICON immunotherapy

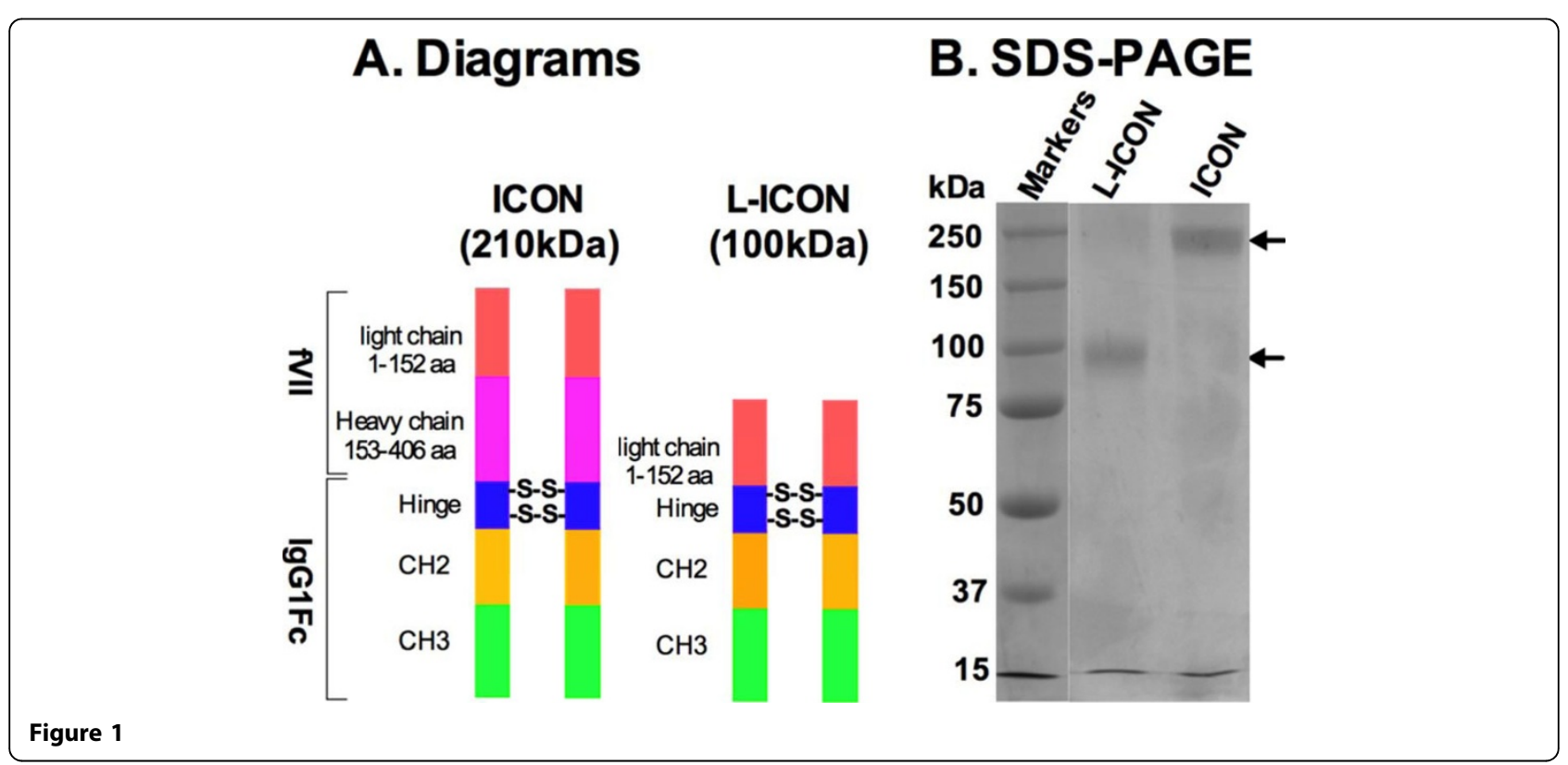

The Ohio State University, Columbus, OH, USA

( $2015 \mathrm{Hu}$ et al. This is an Open Access article distributed under the terms of the Creative Commons Attribution License (http:// 
for the treatment of BRAF mutated melanoma and triple negative breast cancer (TNBC), both of which are very difficult to treat in clinic.

\section{Methods}

L-ICON protein and adenoviral vectors have been developed by recombinant DNA techniques. The binding activity of L-ICON to human melanoma lines with or without BRAF mutant and to human TNBC was assayed by flow cytometry and cell ELISA. Its ADCC effect was determined by an ADCC effector assay (Promega). L-ICON therapy of TNBC via intra-lesional injection of Ad-LICON was compared to Ad-ICON in a nude mouse model of TNBC MDA-MB-231.

\section{Results}

The molecular weight of L-ICON was $100 \mathrm{kDa}$ (Fig. 1), only $50 \%$ of ICON's. L-ICON could bind to human and canine melanoma lines, regardless of their BRAF status. L-ICON could also bind to human TNBC lines, similarly to the first generation ICON. L-ICON could mediate ADCC effect to these cancer cells in vitro. Intra-lesional L-ICON and ICON immunotherapy via adenoviral vectors were similarly effective for the treatment of human TNBC in a nude mouse model.

\section{Conclusions}

L-ICON molecular mass was reduced significantly while its binding activity to cancer cells was intact. L-ICON therapy was effective for the treatment of melanoma and TNBC in vitro and in vivo in a preclinical mouse model.

Published: 4 November 2015

Notes. Z.H. is the inventor of L-ICON and its uses (US Patent Application \# 62/082,891 filed November 2014).

doi:10.1186/2051-1426-3-S2-P304

Cite this article as: Hu et al:: Tissue factor-targeted immunotherapy of melanoma and triple negative breast cancer using a second generation ICON. Journal for ImmunoTherapy of Cancer 2015 3(Suppl 2):P304.
Submit your next manuscript to BioMed Central and take full advantage of:

- Convenient online submission

- Thorough peer review

- No space constraints or color figure charges

- Immediate publication on acceptance

- Inclusion in PubMed, CAS, Scopus and Google Scholar

- Research which is freely available for redistribution

Submit your manuscript at www.biomedcentral.com/submit 